\title{
SUBSTITUIÇÃO FIDEICOMISSÁRIA: QUESTÕES CONTROVERSAS
}

\author{
Ádamo Brasil Dias ${ }^{1}$
}

\section{ORIGEM E EVOLUÇÃO}

O fideicomisso se origina na Roma antiga, no tempo da república, com o intuito de contornar a rigidez da lei escrita que feria de incapacidade sucessória passiva determinadas pessoas, obrigando o testador a buscar uma forma de burlar a norma.

$\mathrm{O}$ que ocorria é que pessoas de classes inferiores a do testador não possuíam os mesmos direitos, inclusive com impossibilidade de apresentarem-se como partes em atos públi$\cos ^{2}$ Todavia, como isso não impedia a geração de um vínculo afetivo com a pessoa do testador, não era incomum que esse quisesse deixar herança ou legado para tais pessoas.

Para transpor o obstáculo legal, o testador pedia ao seu herdeiro que fizesse a entrega do patrimônio ao terceiro que desejava beneficiar. No dizer de Armando Dias de Azevedo3: "esse pedido era votado à boa fé do herdeiro - fidei tua comitto - donde a expressão fideicommissum, da qual derivou fideicomisso." [sic] Vale registrar que o instituto não tinha qualquer amparo legal, de modo que a execução da liberalidade ficava inteiramente confiada à boa-fé, honestidade e honradez do fiduciário. ${ }^{4}$

1 Advogado militante, especialista em Direito Público.

2 MEIRA, José Corrêa de. Do fideicomisso: apontamentos de um juiz sobre as substituições fideicommisarias em geral. Analyse das principaes questões. São Paulo: Livraria Acadêmica Saraiva \& Cia., 1929, p. 11.

3 AZEVEDO, Armando Dias de. Do fideicomisso. Porto Alegre: Boa Imprensa, 1938, p. 5.

4 MEIRA, op. cit., p. 12. 
Como registra Silvio Venosa, inicialmente nada obrigava o fiduciário a cumprir o prometido, a não ser o dever moral. ${ }^{5}$ Ocorre que em determinada ocasião de escandalosa infidelidade do fiduciário, o imperador Augusto determinou que os cônsules impusessem sua autoridade a fim de constranger administrativamente aquele ao cumprimento do fideicomisso. No dizer de Pontes de Miranda, "era o picar da casca do ôvo: o direito nascia". ${ }^{6}$ A partir de então, a intervenção estatal passou a ser normal, sendo criados pelo imperador Claudio os cargos de praetor fideicomissarius para desempenhar tal função, que vieram a ser reduzidos posteriormente para um só, pelo imperador Tito. ${ }^{7}$

Quatro foram as fases por que passou o fideicomisso no direito romano, conforme análise de Moreira Alves: ${ }^{8}$ "em um primeiro momento, a transferência se dava pela venda fictícia, de modo que o fideicomissário figurava como comprador da herança (loco emptoris); em um segundo período, com o senatusconsulto Trabaliano, o fideicomissário é reputado herdeiro pretoriano (loco heredis); em momento histórico seguinte, é tido ora como herdeiro pretoriano, ora como legatário parciário; por fim, no quarto período do fideicomisso, o fideicomissário é tido como verdadeiro herdeiro".

O fideicomisso passou então a ser amplamente utilizado, chegando ao ponto de desnaturar-se o instituto em dado período, quando possível que fosse perpétuo. Visando a corrigir isso e evitar a imobilização de bens, Justiniano reduziu-o ao quarto grau. ${ }^{9}$ Podiam ser objeto de fideicomisso coisas singulares como terrenos, escravos, roupas, prata ou dinheiro. ${ }^{10}$ Ademais, somente pelo fideicomisso era permitido conferir liberdade a um escravo. ${ }^{11}$

5 VENOSA, Silvio de Salvo. Direito civil: direito das sucessões. 6. ed. São Paulo: Atlas, 2006, p. 287.

6 PONTES DE MIRANDA, Francisco Cavalcanti. Tratado de direito privado. t. LVIII. atualizado por Giselda Hironaka, Paulo Lôbo. São Paulo: Editora Revista dos Tribunais, 2012, p. 191-192.

7 AZEVEDO, Armando Dias de. O Fideicomisso no Direito Pátrio: Doutrina, Legislação, Jurisprudência. São Paulo: Saraiva, 1973, p. 4.

8 MOREIRA ALVES, José Carlos. Direito Romano. 14. ed. Rio de Janeiro: Editora Forense, 2008, p. 819.

9 Ibidem, p. 4-5.

10 GAIUS. Institutas do jurisconsulto Gaio. Tradução: CRETELLA Jr., J.; CRETELLA, Agnes. São Paulo: Editora Revista dos Tribunais, 2004, p. 124.

11 Ibidem, p. 126. 
O direito canônico aproveitou o instituto ${ }^{12}$ mantendo-o em vigor a fim de assegurar a transmissão dos bens a obras pias ou ordens religiosas, cabendo a um clérigo o desempenho da função que até então era do pretor fideicomissário. $^{13}$

Entretanto, foi na Idade Média que o instituto se consolidou, ganhando grande importância para conservar o patrimônio familiar reunido, o qual era passado de geração em geração normalmente ao filho primogênito ${ }^{14}$ - por meio dos morgados. Segundo Venosa, "o morgadio era uma forma feudal para se manter a terra com as famílias dos senhores". ${ }^{15}$ Como disse Pontes de Miranda,

o feudalismo encontrou nos fideicomissos o molde jurídico que se prestava à sua índole política e social, ao orgulho e espírito de conservação de seu tempo. Desenvolveu-o. Usou dele, e dele abusou. A injustiça social das hereditariedades econômicas chegou ao requinte. São os morgados, os vínculos. Vemo-los perdurar de pais a filhos, a netos, a bisnetos, cada geração com o mesmo séquito de credores. $^{16}$

Diante de tais abusos, o fideicomisso acabou por ser afastado do ordenamento francês no período. ${ }^{16}$ Em alguns ordenamentos, a vedação persiste até os tempos atuais, o que é destacado pela doutrina argentina ${ }^{18}$, aludindo ao art. 3.723 do Código Civil $\operatorname{argentino~}^{19}$, e italiana ${ }^{20}$, art. 627 do Código Civil italiano ${ }^{21}$, em que as hipóteses de fideicomisso são excepcionalíssimas.

O instituto foi acolhido pelo direito português, embora tenha recebido

12 AZEVEDO, op. cit., p. 7.

13 VENOSA, op. cit., p. 287-288.

14 WALD, Arnoldo. Curso de direito civil brasileiro: direito das sucessões. V. 5. 8. ed. São Paulo: Editora Revista dos Tribunais, 1991, p. 167.

15 VENOSA, op. cit., p. 287-288.

16 PONTES DE MIRANDA, op. cit., p. 192.

17 Ibidem, p. 192.

18 ZANNONI, Eduardo A. Manual de derecho de lãs sucesiones. 4. ed. Buenos Aires: Editorial Astrea, 1999, p. 603-604.

19 El derecho de instituir un heredero no importa el derecho de dar a éste un sucesor. 20 BIANCA, C. Massimo. Diritto Civile. La famiglia. Le successioni, V. 2. 3. ed. Milano: Giuffrè, 2001, p. 716.

21 Non è ammessa azione in giudizio per accertare che le disposizioni fatte a favore di persona dichiarata nel testamento sono soltanto apparenti e che in realtà riguardano altra persona, anche se espressioni del testamento possono indicare o far presumere che si tratta di persona interposta. 
pouco tratamento positivado, cabendo aos costumes papel importante. ${ }^{22}$ As Ordenações Afonsinas e Manuelinas silenciaram sobre o instituto, que foi abordado apenas nas Ordenações Filipinas de forma superficial e incompleta, conforme registrou Armando Dias de Azevedo em monografia sobre o tema. ${ }^{23}$ Em outra obra, o mesmo autor resgata importante exemplo de fideicomisso caracterizado na realeza portuguesa:

é clássico o caso da rainha Santa Isabel, já viúva do rei D. Diniz, o Lavrador, que, em seu testamento, incluiu este legado: "Mando a minha coroa de esmeraldas à rainha $\mathrm{D}$. Beatriz, minha filha, e rogo-lhe que a deixe à infanta $\mathrm{D}$. Maria, sua filha". Típico fideicomisso, embora não empregasse, na deixa, tal palavra, que, aliás, como se verá mais adiante, nunca foi sacramental. ${ }^{24}$

O fideicomisso ingressou no Brasil por meio das Ordenações filipinas, que vigoraram até o último dia do ano de 1916 - as quais paradoxalmente já estavam revogadas meio século antes em Portugal. ${ }^{25}$

Após uma série de tentativas infrutíferas de codificação civil, cuja tarefa circulou por pelo menos cinco diferentes nomes de peso, foi em 1900 que Clóvis Beviláqua encaminhou a uma comissão revisora da Câmara dos Deputados o projeto de código civil. Apenas em $1^{\circ}$ de janeiro de 1916 , não sem atender a uma série de correções apontadas por Rui Barbosa, ${ }^{26} \mathrm{o}$ Código Civil veio a ser promulgado. Nesse processo legislativo, a substituição fideicomissária esteve a risco de ser suprimida do código devido a uma vitória por maioria no Senado nesse sentido. Todavia, a Câmara de Deputados restabeleceu o instituto, restando intacto o texto revisto por Rui Barbosa. ${ }^{27}$

Essa ameaça de retirada do fideicomisso da legislação brasileira quando da elaboração do Código Civil de 1916 tinha por fundamento a inutilidade do instituto, o que evidentemente não era verdadeiro, uma vez que o instituto possui grande potencial de

22 WALD, op. cit., p. 167.

23 AZEVEDO, Armando Dias de. Do fideicomisso. Porto Alegre: Boa Imprensa, 1938, p. 7.

24 Idem. O Fideicomisso no Direito Pátrio: Doutrina, Legislação, Jurisprudência. São Paulo: Saraiva, 1973, p. 11.

25 Ibidem, p. 13.

26 Importante destacar que todas as emendas relativas ao fideicomisso foram aceitas pelo Congresso Nacional.

27 Ibidem, p. 14-15. 
utilidade quando há o intento de beneficiar uma pessoa que ainda não exista quando da abertura da sucessão. ${ }^{28}$

Sofrendo algumas alterações na transição do Código Civil de 1916 para o atual, o fideicomisso permanece inserido como modalidade de substituição, ao lado da substituição vulgar, na qual a substituição ocorre somente na ausência do substituído contrapondo-se à substituição fideicomissária, em que a vocação ocorre em favor de ambos. ${ }^{29}$

\section{CONTORNOS}

O fideicomisso teve lugar garantido em nosso sistema especialmente por conferir ao testador a possibilidade de assegurar a destinação de herança a pessoa ainda não concebida ao tempo da abertura da sucessão, o que torna incontestável a sua utilidade, no entender de Silvio Venosa. ${ }^{30}$

Aliás, por essa mesma razão, ainda no início do século passado, José Corrêa de Meira ${ }^{31}$ destacava que mes- mo nos países mais resistentes ao fideicomisso, a exemplo da França, houve o reconhecimento de sua utilidade como meio para deixas testamentárias em favor daqueles que ainda não haviam sido concebidos.

Como bem apontado pela doutrina, ${ }^{32}$ é possível elencar três requisitos indispensáveis à caracterização da substituição fideicomissária, a saber:

a) Dupla vocação hereditária, uma vez que ao mesmo tempo são instituídos dois herdeiros ou legatários, um fiduciário e outro fideicomissário.

b) Ordem sucessiva que exige a ocorrência do evento resolutivo, seja ele decorrente de condição, termo ou morte do fiduciário.

c) Dever de conservação dos bens pelo fiduciário, que deverão ser destinados ao fideicomissário no momento oportuno.

Há quem inclua ainda como um quarto requisito a obrigatoriedade de que o fideicomissário não tenha sido concebido à data da abertura da sucessão. $^{33}$

28 MALUF, Nagib Antônio. Fideicomisso no Direito Brasileiro. São Paulo: Hemus, 1987 , p. 18.

29 WALD, op. cit., p. 162.

30 VENOSA, op. cit., p. 297.

31 MEIRA, op. cit., p. 34.

32 GOMES, Orlando. Sucessões. 12. ed. Rio de Janeiro: Editora Forense, 2004, p. 213.

33 CARVALHO, Luiz Paulo Vieira de. Direito das sucessões: das substituições no Código Civil de 2002. In: Revista de Direito do Tribunal de Justiça do Rio de Janeiro. Rio de Janeiro, n. 66, p. 42-59, jan. 2006. 
É importante que se perceba que os requisitos não podem sofrer distorção interpretativa, o que acabaria por desvirtuar o instituto, como, por exemplo, a hipótese em que o testador estabelece uma condição para que determinada pessoa suceda, o que por certo não é a mesma coisa que estabelecer uma condição para a resolução da propriedade do fiduciário. Arnaldo Rizzardo esclarece que

não se trata de fideicomisso, mas de substituição testamentária, quando, não realizada uma condição, é estipulado que os bens vão a outra pessoa, já vindo indicada ou esclarecido quem irá receber. Há, aí, testamento sob condição, como aparece neste caso: "O testador demonstrou ser de sua vontade que os bens correspondentes fossem aos filhos consanguíneos de sua filha, se ela os tivesse; se não os tivesse, os bens iriam a seus netos, dele testador (verificados ao tempo de sua morte ou da abertura da sucessão, numa clara disposição em favor da prole eventual de seus outros filhos). Não verificada a condição resolutiva, os bens postos sob fideicomisso passavam (como passaram) à propriedade definitiva dos fideicomissários. ${ }^{34}$

Outro aspecto relevante a ser considerado é o dever de conservação dos bens pelo fiduciário, uma vez que isso suscita de imediato a dúvida sobre se estar diante de caso de inalienabilidade ou não.

Silvio Venosa ${ }^{35}$ esclarece que o bem fideicomitido poderá ser gravado com cláusula de inalienabilidade, de modo que, sendo uma faculdade, não se trata de uma consequência automática do fideicomisso. Aliás, Armando Dias de Azevedo é categórico ao afirmar que a alienabilidade no fideicomisso nunca se presume. ${ }^{36}$ Nessa linha, consoante magistério de Silvio Rodrigues "quando o testador realmente deseja que os bens fideicomitidos cheguem às mãos do fideicomissário, deve impor a cláusula da inalienabilidade". ${ }^{37}$

Segundo Pontes de Miranda, ${ }^{38}$ a alienação feita a terceiros é válida, não podendo haver reivindicação do fideicomissário em nenhum tempo, sendo resguardado o direito de ação

34 RIZZARDO, Arnaldo. Direito das sucessões: Lei n ${ }^{\circ}$ 10.406, de 10.01.2002. 2. ed. Rio de Janeiro: Forense, 2005, p. 495.

35 VENOSA, op. cit., p. 290.

36 AZEVEDO, op. cit., p. 78.

37 RODRIGUES, Silvio. Direito civil: direito das sucessões, V. 7. 26. ed. São Paulo : Saraiva, 2003, p. 248.

38 PONTES DE MIRANDA, op. cit., p. 226-227. 
contra o fiduciário. Por outro lado, Caio Mário da Silva Pereira ${ }^{39}$ entende que por ser a propriedade do fiduciário resolúvel, necessariamente ocorrerá a resolução das alienações feitas a terceiros quando chegar o momento de transmitir a herança ou o legado ao fideicomissário.

Diante desse impasse, parece acertada a solução apontada por Silvio Venosa, ${ }^{40}$ segundo a qual deverá ser levada em consideração a boa-fé do terceiro adquirente, a qual estará em crise quando houver sido averbado o fideicomisso na matrícula do imóvel fideicomitido antes da transferência ao domínio daquele.

Por outro lado, dúvidas surgem quanto à validade da disposição testamentária que confere ao fiduciário o direito de dispor livremente dos bens fideicomitidos, incumbindo-lhe tão somente o dever de transferir ao fideicomissário o que sobrar. A tal espécie a doutrina dá o nome de fideicomisso de resíduo.

No entendimento adotado por Armando Dias de Azevedo, ainda na vigência do código anterior, não haveria qualquer restrição ao fideicomisso de resíduo, se fosse da vontade do testador e houvesse menção expressa a tal direito excepcional do fiduciário. Desejando o fideicomitente que os bens chegassem integralmente ao fideicomissário, bastaria não dispor nada a respeito ou, ainda, gravar os bens com cláusula de inalienabilidade. ${ }^{41}$ A doutrina parece inclinar-se nesse sentido. ${ }^{42}$

Uma vez gravado o bem fideicomitido com cláusula de inalienabilidade, a sub-rogação do bem por outro é questão que gera cisão entre os autores. Silvio Venosa ${ }^{43}$ esposa a ideia de que sendo possível a sub-rogação em outros bens ordinariamente gravados com a inalienabilidade, não haveria motivos para deixar de adotar o mesmo procedimento com relação aos bens fideicomitidos. Por outro lado, há autores sustentando entendimento contrário, arguindo que isso implicaria em descumprimento da vontade do testador. ${ }^{44}$ Os argumentos de ambas as correntes são fortes, de modo que são os elementos fáticos de cada caso que apontarão o caminho a seguir. Sope-

39 PEREIRA, Caio Mário da Silva. Instituições de Direito Civil: direito das sucessões. v. 4. 17. ed. Rio de Janeiro: Editora Forense, 2009, p. 277.

40 VENOSA, op. cit., p. 289.

41 AZEVEDO, op cit., p. 78.

42 CARVALHO, op. cit., p. 54.

43 VENOSA, op. cit., p. 294.

44 CARVALHO, op. cit., p. 53. 
sando os interesses em discussão no caso concreto, caberá ao juiz a pesada responsabilidade de solucionar a lacuna legal.

\subsection{Sujeitos}

Tratando-se de espécie peculiar de substituição, necessariamente três serão os integrantes da relação estabelecida pelo fideicomisso: o fideicomitente, situado na pessoa do testador; o fiduciário, que é o primeiro a suceder e possui propriedade restrita e resolúvel; ${ }^{45}$ e, por fim, o fideicomissário, titular de um direito eventual de receber a herança quando ocorrido o termo ou a condição estabelecidos, ou, ainda, quando da morte do fiduciário. ${ }^{46}$

Ao fideicomitente cumpre o dever de observar as limitações do fideicomisso, sob pena de inviabilizar a caracterização do instituto. $\mathrm{O}$ fideicomisso não deverá recair sobre a legítima ${ }^{47}$ nem poderá ir além da pessoa do fideicomissário, estando vedado o fideicomisso além do segundo grau, ${ }^{48}$ sob pena de nulidade das disposições que exorbitem tal limite. Caso inobservada tal regra, valerá o fideicomisso apenas até o fideicomissário segundo Venosa. ${ }^{49}$ Silvio Rodrigues também adere a esta corrente..$^{50}$

Com entendimento diferente, Caio Mário da Silva Pereira entende que "se invalida a cláusula determinante da substituição, mas prevalece a deixa, instituída em favor do fiduciário, que destarte recebe os bens em propriedade plena e livre," ${ }^{51}$ posição esta também adotada por Clóvis Bevilaqua. ${ }^{52}$ Há que se tecer crítica aos eminentes autores, pois o raciocínio parece pouco razoável, haja vista que iria de encontro à vontade manifesta do testador de beneficiar em definitivo o fideicomissário.

O segundo sujeito nesta relação é o fiduciário, que se apresenta como o primeiro sucessor, com propriedade

$45 \mathrm{CC} / 02$, art. 1.953. O fiduciário tem a propriedade da herança ou do legado, mas restrita e resolúvel.

46 VENOSA, op. cit., p. 286.

47 RODRIGUES, op. cit., p. 244.

$48 \mathrm{CC} / 02$, art. 1.959. São nulos os fideicomissos além do segundo grau.

49 VENOSA, op. cit., p. 289.

50 RODRIGUES, op. cit., p. 249.

51 PEREIRA, op. cit., p. 279.

52 BEVILAQUA, Clóvis. Direito das sucessões. 3. ed. Rio de Janeiro: Livraria Editora Freitas Bastos, 1938, p. 542. 
resolúvel. Ainda que possua a propriedade do bem, deverá o fiduciário administrar o bem recebido com diligência, inclusive respondendo pelos encargos e pelas despesas de conservação, responsabilizando-se pelos danos causados ao patrimônio fideicomitido quando incorrer em culpa, consoante tradicional ensinamento de Arnoldo Wald. ${ }^{53}$ Tal como já era tratado no Código Civil de 1916, estará obrigado o fiduciário à prestação de caução quando exigir o fideicomissário, a fim de assegurar que os bens serão restituídos. ${ }^{54}$

Cumpre ao fiduciário também inventariar os bens fideicomitidos, ${ }^{55}$ podendo vir a ser compelido judicialmente a pedido dos interessados na herança, dentre os quais o fideicomissário e o testamenteiro, inclusive com a possibilidade de ser impedido de ingressar na posse dos bens até que atenda ao dever de inventário. ${ }^{56}$
Em compensação, "o fiduciário tem direito aos frutos percebidos e poderá realizar as modificações necessárias à melhor utilização do bem, podendo levantar as benfeitorias realizadas, tendo direito de retenção caso não haja pagamento da indenização pelas benfeitorias necessárias e úteis." ${ }^{57}$ No magistério de Pontes de Miranda, terá o fiduciário direito ao reembolso quando custear despesas extraordinárias que se revelaram necessárias, salvo no caso de ter sido utilizado patrimônio da própria herança para cobri-las. ${ }^{58}$

Como último sujeito a compor a tríade, o fideicomissário será necessariamente pessoa ainda não concebida à data da abertura da sucessão, nos termos do art. 1.952 do Código Civil. ${ }^{59}$ Isso remete à dificuldade identificada por Pontes de Miranda ${ }^{60}$ no Código anterior ao falar em "prole eventual", uma vez que

53 WALD, op. cit., p. 168.

54 SOUZA, Orlando de. Prática dos testamentos. 1. ed. São Paulo: Sugestões Literárias S/A, 1969, p. 129-130.

55 CC/02, Art. 1.953, Parágrafo único. O fiduciário é obrigado a proceder ao inventário dos bens gravados, e a prestar caução de restitui-los se o exigir o fideicomissário.

56 VENOSA, op. cit., p. 294.

57 GAMA, Guilherme Calmon Nogueira da. Substituições e fideicomisso. In: HIRONAKA, Giselda Maria Fernandes Novaes; PEREIRA, Rodrigo da Cunha. Direito das sucessões e o novo código civil. Belo Horizonte: Del Rey, 2004, p. 331-354.

58 PONTES DE MIRANDA, op. cit., p. 247.

$59 \mathrm{CC} / 02$, art. 1.952. A substituição fideicomissária somente se permite em favor dos não concebidos ao tempo da morte do testador.

60 PONTES DE MIRANDA, op. cit., p. 75. 
havia alguns conflitos de interpretação decorrentes de tão incerto termo, que felizmente não se repete na lei atual.

Orlando Gomes descreve o fideicomissário como sendo "o herdeiro, ou legatário, que tem direito eventual a receber a herança, ou o legado, deferidos ao fiduciário precisamente para restitui-los a ele." 61

Embora seja assegurado ao fideicomissário o direito de adotar as providências necessárias para defender os seus interesses, ${ }^{62}$ não poderá anular as vendas feitas pelo fiduciário, haja vista que esse só poderá vender aquilo que possui, ou seja, um direito de propriedade resolúvel. Caso o faça, o adquirente dos bens fideicomitidos terá a propriedade apenas até o momento em que for resolvido o fideicomisso, ocasião em que o domínio passará por completo ao fideicomissário. ${ }^{63}$

Por essa mesma razão, entende Guilherme Calmon Nogueira da
Gama que não havendo vedação no testamento poderá o fideicomissário dispor do seu direito eventual por meio de cessão de direito em favor de terceiro. ${ }^{64}$ Nessa esteira, Arnoldo Wald adotou entendimento de que a cessão seria possível desde que a transferência estivesse subordinada a termo fixo, pois se fosse por morte do fiduciário estar-se-ia diante de possível pacto sucessório, vedado pelo ordenamento pátrio. ${ }^{65}$

No que toca ao direito de aceitar ou repudiar a herança, a renúncia do fideicomissário implicará na caducidade do fideicomisso nos termos do art. 1.955 do mesmo diploma. ${ }^{66}$ Por outro lado, "a renúncia do fiduciário à herança ou ao legado atribui ao fideicomissário o poder de aceitar o benefício sucessório, salvo disposição diversa feita pelo testador", ${ }^{67}$ conforme previsão do art. 1.954 do Código Civil. ${ }^{68}$

Nesse particular, é oportuno confrontar o referido dispositivo com o

61 GOMES, op. cit., p. 216.

$62 \mathrm{CC} / 02$, Art. 130. Ao titular do direito eventual, nos casos de condição suspensiva ou resolutiva, é permitido praticar os atos destinados a conservá-lo.

63 WALD, op. cit., p. 168.

64 GAMA, op. cit.

65 WALD, op. cit., p. 168-169.

66 Art. 1.955. O fideicomissário pode renunciar a herança ou o legado, e, nesse caso, o fideicomisso caduca, deixando de ser resolúvel a propriedade do fiduciário, se não houver disposição contrária do testador.

67 GAMA, op. cit.

68 Art. 1.954. Salvo disposição em contrário do testador, se o fiduciário renunciar à herança ou ao legado, defere-se ao fideicomissário o poder de aceitar. 
parágrafo único ${ }^{69}$ do art. 1.952 , pois há aparente incongruência sistemática. É que embora ao nascituro sejam resguardados direitos, enquanto não nascer com vida não terá capacidade civil para exercer a aceitação sobre a qual alude o art. 1.954. E isso só piora quando o fideicomissário sequer foi concebido. Por outro lado, se já houver nascido (com vida), então não haverá necessidade de qualquer aceitação, uma vez que será aplicável o disposto no parágrafo único do art. 1.952 do mesmo diploma e, por conseguinte, o fideicomissário assumirá a nua-propriedade. A questão parece complicar-se ainda mais quando Orlando Gomes ${ }^{70}$ defende que "a renúncia não poderá ocorrer no momento da abertura da sucessão, pois o fideicomisso só pode ser instituído em favor de pessoas não concebidas", haja vista que isso leva à ideia de que pelo mesmo motivo a aceitação também não poderia ocorrer.

Entretanto, a incongruência é apenas aparente, uma vez que ao nasci- turo será conferido curador, ${ }^{71}$ a quem competirá exercitar os atos necessários à conservação dos seus direitos. E mais, havendo interesse de menor ou incapaz, o inventário necessariamente se processará judicialmente e sob fiscalização do Ministério Público, de modo que eventual repúdio ou aceitação da herança pelo curador do fideicomissário (nascituro) necessariamente deverá levar em consideração o melhor interesse do incapaz.

Ainda no que diz respeito aos sujeitos envolvidos, parece relevante trazer a lume as figuras dos fideicomissos eletivos ${ }^{72}$ abordadas por Pontes de Miranda em sua maior obra.

$\mathrm{O}$ eminente jurista defendia a viabilidade dos fideicomissos eletivos, nos quais caberia ao fiduciário a escolha do fideicomissário, fundamentando seu entendimento na faculdade trazida pelo art. 1.668 , I, do antigo Código ${ }^{73} \mathrm{em}$ que era possível instituir herdeiro pessoa incerta a ser determinada por terceiro. O atual art. 1901,

69 Art. 1.952, parágrafo único. Se, ao tempo da morte do testador, já houver nascido o fideicomissário, adquirirá este a propriedade dos bens fideicometidos, convertendo-se em usufruto o direito do fiduciário.

70 GOMES, op. cit., p. 218.

71 Art. 1.779. Dar-se-á curador ao nascituro, se o pai falecer estando grávida a mulher, e não tendo o poder familiar.

72 PONTES DE MIRANDA, op. cit., p. 215.

$73 \mathrm{CC} / 16$, Art. 1.668. Valerá, porém, a disposição: I. Em favor de pessoa incerta que deva ser determinada por terceiro, dentre diversas pessoas mencionadas pelo testador, ou pertencentes a uma família, ou a um corpo collectivo, ou a um estabelecimento por elle designado. 
I, do Código Civil possui idêntica redação, o que implicaria a necessária aceitação dos fideicomissos eletivos se adaptados às exigências hodiernas da substituição fideicomissária.

\subsection{Momentos}

Nos termos do art. 1.951 do Código Civil, ${ }^{74}$ o direito do fiduciário pode ser resolvido em favor do fideicomissário em decorrência de termo, condição ou morte daquele, ${ }^{75}$ o que inevitavelmente remete à necessidade de observância das disposições da parte geral do mesmo diploma (art. $121 \mathrm{e}$ seguintes).

Importa dizer, o fideicomisso possui basicamente dois momentos: ${ }^{76}$ o primeiro é a abertura da sucessão, ocasião em que se verifica a dupla vocação hereditária, mas a herança ou legado ingressa no domínio do fiduciário; o segundo momento se verifica quando da ocorrência do gatilho previsto pelo testador condição, termo ou morte do fiduciário
- para que o patrimônio chegue ao seu destinatário final, o fideicomissário.

Por ser o fideicomisso no Brasil autorizado tão somente em favor dos não concebidos à data da abertura da sucessão, revela-se imperiosa a aplicação do disposto no art. 1.800, $\S 4^{\circ}$, do Código Civil, ${ }^{77}$ de modo a não tornar interminável a espera pela prole eventual. Isso pode criar algumas dificuldades interpretativas no tocante ao momento em que terá início a contagem do prazo de dois anos para o nascimento do herdeiro esperado.

Por tal razão, a fim de evitar que o direito se consolide na mão do fiduciário, o que tornaria inócua a substituição fideicomissária e acabaria por desatender à vontade do testador, é de se cogitar que a contagem do prazo para a concepção do herdeiro não se inicie na abertura da sucessão, mas sim no momento em que se opera a condição, termo ou morte do fiduciário. ${ }^{78}$ Até mesmo porque, embora o fiduciário seja também herdeiro, é

74 Art. 1.951. Pode o testador instituir herdeiros ou legatários, estabelecendo que, por ocasião de sua morte, a herança ou o legado se transmita ao fiduciário, resolvendo-se o direito deste, por sua morte, a certo tempo ou sob certa condição, em favor de outrem, que se qualifica de fideicomissário.

75 GAMA, op. cit., p. 331-354.

76 PONTES DE MIRANDA, op. cit., p. 205.

77 Art. $1.800, \S 4^{\circ}$. Se, decorridos dois anos após a abertura da sucessão, não for concebido o herdeiro esperado, os bens reservados, salvo disposição em contrário do testador, caberão aos herdeiros legítimos.

78 CARVALHO, op. cit. 
fato que o fideicomissário é o destinatário final da herança, o que suscitaria a aplicação do art. 133 do Código Civil, ${ }^{79}$ no sentido de ser adotada interpretação do testamento que seja mais benéfica ao herdeiro definitivo.

Entretanto, a questão não é pacífica. Adotando entendimento diametralmente oposto, Guilherme Calmon Nogueira da Gama defende que

caso não tenha ocorrido a concepção do fideicomissário até o momento da resolução do direito do fiduciário, é de se reconhecer a caducidade do fideicomisso, consolidando-se a propriedade no fiduciário (nas hipóteses de termo ou condição) ou nos seus herdeiros (no caso de morte do fiduciário). A única hipótese em que não haveria caducidade do fideicomisso seria a da previsão testamentária expressa a respeito de um prazo de espera para a concepção do fideicomissário, mesmo após se ter operado a resolução do direito do fiduciário. ${ }^{80}$

Embora a casuística possa criar uma série de complicações quando da aplicação da norma, parece-nos que a primeira corrente tende a sintonizarse melhor com a sistemática adotada pelo Código, buscando preservar ao máximo a vontade do testador. A título de exemplo, poder-se-ia imaginar a situação em que o testador pretende deixar determinado legado ao seu primeiro neto, que deverá recebê-lo quando da morte do fiduciário. Ocorre que o fiduciário vem a falecer dois anos após a morte do testador, dias antes de o fideicomissário vir a ser concebido. Se a contagem do prazo de dois anos para nascimento do fideicomissário tivesse início quando da morte do testador, então no presente exemplo o legado passaria à sucessão do fiduciário em definitivo por haver caducado o fideicomisso. Com isso, estar-se-ia a adotar interpretação contrária à vontade do testador, além de ser contrária à orientação do art. 133 do Código Civil.

A adoção de interpretação gramatical do $\S 4^{\circ}$ do art. 1.800 conduz com mais facilidade à conclusão de que a contagem do prazo tem início com a abertura da sucessão e não com o implemento da hipótese prevista pelo testador para que ocorra a transferência patrimonial ao fideicomissário. Entretanto, esse não parece ser o espírito da lei, de modo que uma interpretação gramatical pura traria grave

79 Art. 133. Nos testamentos, presume-se o prazo em favor do herdeiro, e, nos contratos, em proveito do devedor, salvo, quanto a esses, se do teor do instrumento, ou das circunstâncias, resultar que se estabeleceu a benefício do credor, ou de ambos os contratantes.

80 GAMA, op. cit. 
risco de ferir o intento do legislador de proteger a vontade do testador. É válido o alerta de Luís Roberto Barroso de que "embora o espírito da norma deva ser pesquisado a partir de sua letra, cumpre evitar excesso de apego ao texto, que pode conduzir à injustiça, à fraude e até ao ridículo." $" 1$

Daí que, sabendo-se que o Código busca preservar a vontade do testador, uma vez que esse não estará mais presente para esclarecê-la quando do cumprimento do testamento, é mais razoável a utilização de interpretação teleológica ${ }^{82}$ e sistemática ${ }^{83}$ a fim de não sacrificar justamente aquilo que mais se busca proteger nas disposições de última vontade.

Todavia, há que se reconhecer que essa interpretação pode vir a gerar um problema nos casos em que o fiduciário renuncia à herança antes mesmo de o fideicomissário ter sido concebido. Nesse caso, a doutrina que detectou o problema ${ }^{84}$ defende que a herança fique sob os cuidados de um administrador até que seja o fideicomissário concebido ou esgotese o prazo para isso.

\subsection{Caducidade}

A caducidade do fideicomisso é a ineficácia da disposição nos moldes da substituição fideicomissária decorrente de algumas ocorrências posteriores ao testamento. Orlando Gomes ${ }^{85}$ enumera seis possibilidades: a) a incapa-

81 BARROSO, Luís Roberto. Interpretação e aplicação da constituição: fundamentos de uma dogmática constitucional transformadora. 4. ed. rev. e atual. - São Paulo: Saraiva, 2001, p. 127.

82 George Salomão Leite esclarece que "através do elemento teleológico busca-se a ratio legis, a razão da lei. Nela o intérprete procura conhecer a finalidade, o valor que está por trás do enunciado prescritivo." (LEITE, George Salomão. Interpretação Constitucional e Tópica Jurídica. São Paulo: Juarez de Oliveira, 2002, p. 33.)

83 Segundo Luís Roberto Barroso, "o método sistemático disputa com o teleológico a primazia no processo interpretativo. O direito objetivo não é um aglomerado aleatório de disposições legais, mas um organismo jurídico, um sistema de preceitos coordenados ou subordinados, que convivem harmonicamente. A interpretação sistemática é fruto da ideia de unidade do ordenamento jurídico. Através dela, o intérprete situa o dispositivo a ser interpretado dentro do contexto normativo geral e particular, estabelecendo as conexões internas que enlaçam as instituições e as normas jurídicas". (BARROSO, op. cit, p. 136.)

84 BORGHI, Hélio. O novo Código Civil e as inovações no direito das sucessões: a nova forma de substituição fideicomissária. In: Revista de Direito Privado, V. 8, n. 31, p. 91-118.

85 GOMES, op. cit., p. 217. 
cidade sucessória do fideicomissário; b) a morte do fideicomissário anterior à do fiduciário (art. 1.958); c) o nascimento do fideicomissário antes da morte do testador (art. 1.950, parágrafo único); d) a morte do fideicomissário antes de realizada a condição resolutória prevista (art. 1.958); e) a renúncia (art. 1.955); f) o perecimento da coisa sem culpa do fiduciário (art. 1.939, III). ${ }^{86}$

No que diz respeito à renúncia pelo fideicomissário, que sempre deverá ser expressa mediante escritura pública ou termo judicial, ${ }^{87}$ via de regra não ocorrerá quando da abertura da sucessão, haja vista que aquele normalmente não terá sido concebido ainda, nos termos do art. 1.952 do Código Civil. Por outro lado, já tendo nascido o fideicomissário quando da abertura da sucessão, converter-se-á o fideicomisso em usufruto, nos termos do art. 1.952, parágrafo único, do Código Civil.

Arnoldo Wald elenca a renúncia do fiduciário como causa de caducidade também. Nessa esteira, Silvio Venosa alerta que pode ocorrer de o fiduciário renunciar à herança antes de ter sido concebido o fideicomissário, hipótese em que os bens deveriam ser entregues aos cuidados de um administrador até que sobrevenha a prole eventual aguardada. Entretanto, tendo em vista que não prevê a lei essa hipótese, o ideal é que o testamento traga previsão nesse sentido, inclusive com prazo para o encargo do administrador. ${ }^{89}$

Outra questão que suscita debates na doutrina é a hipótese em que o fiduciário morre antes da implementação da condição ou do termo previsto para a transferência da herança ao fideicomissário. Nestes casos, Silvio Venosa entende que se não houver previsão no testamento a respeito e nem qualquer disposição que proíba, o mais lógico seria que os bens fossem passados ao fideicomissário. ${ }^{90}$

Pontes de Miranda adotou posicionamento diverso:

aqui, o fiduciário recolheu a herança e a mantém, mas, antes de dever entregá-la, morre. Pode o fideicomissário pedi-la? Preliminarmente, se o testador quis que só aos 30 anos se entregasse o bem ao

86 Neste caso, não ocorrerá a caducidade se houver sub-rogação no valor de seguro estipulado sobre os bens. (PEREIRA, Caio Mário da Silva. Instituições de Direito Civil: direito das sucessões. v. 4. 17. ed. Rio de Janeiro: Editora Forense, 2009, p. 279.)

87 SOUZA, op. cit., p. 130.

88 WALD, op. cit., p. 169.

89 VENOSA, op. cit., p. 292-293.

90 Ibidem, p. 293. 
fideicomissário, ou se se formar em direito, não se pode cogitar de entrega cuja condenação ressalta $e x$ voluntate. $\mathrm{Ou}$ os bens ficarão com os herdeiros do fiduciário, ou com o testamenteiro; só o testamento poderá decidir, presumindo-se que o testador tenha querido que fique com os herdeiros do fiduciário. Se o termo ou condição só se referia ao interesse do fiduciário que, com a morte, desaparece, a situação é diferente: presumese que o testador quis a passagem, desde logo, ao fideicomissário. ${ }^{91}$

Parece ser essa última linha de raciocínio a que mais se coaduna com a sistemática do fideicomisso. Aliás, esse é também o entendimento adotado por Caio Mario da Silva Pereira, que ainda esclarece que havendo pluralidade de fiduciários, a substituição só ocorrerá com a morte do último. ${ }^{92}$

Ora, se o fiduciário possui a propriedade, ainda que resolúvel, o destino de tais bens deverá ser a sua própria sucessão, salvo nos casos em que a causa para a substituição fideicomissária for a sua morte. Portanto, enquanto não satisfeita a condição ou alcançado o termo, conforme exemplo anterior trazido por Pontes de Miranda, não es- tará resolvido o fideicomisso, devendo ser transferida a propriedade resolúvel aos sucessores do fiduciário. Sustentar raciocínio contrário alçaria a morte do fiduciário a uma posição de preferência em relação às hipóteses de estabelecimento de termo ou condição, uma vez que essas causas de resolução do fideicomisso seriam sempre suprimidas quando viesse o fiduciário a falecer. Com isso, estar-se-ia a dar ao fideicomisso solução idêntica à conferida ao usufruto, institutos que não se confundem.

Além das hipóteses de caducidade já elencadas, Luiz Paulo Vieira de Carvalho acrescenta ainda a hipótese de exclusão do fiduciário. ${ }^{93}$ Todavia, parece ser necessário algum cuidado na consideração da hipótese, uma vez que se aplicaria sem maiores perquirições apenas nos casos em que o fideicomitente houvesse estipulado a morte do fiduciário como causa de resolução do fideicomisso. Tendo sido estipulado termo ou condição, o raciocínio a ser feito deverá ser o mesmo abordado no parágrafo anterior.

Silvio Venosa ${ }^{94}$ atenta ainda a outra questão, não prevista pela lei, que é o de indignidade do fideicomissário em

91 PONTES DE MIRANDA, op. cit., p. 229.

92 PEREIRA, op. cit., p. 278.

93 CARVALHO, op. cit., p. 57.

94 VENOSA, Silvio de Salvo. Direito civil: direito das sucessões. 6. ed. São Paulo: Atlas, 2006, p. 291. 
relação ao fiduciário. No entendimento do autor, seria sumamente imoral que o fideicomissário recebesse os bens se atentasse contra a vida do fiduciário, por exemplo, ou incorresse em alguma das outras hipóteses elencadas pelo art. 1.814 do Código Civil..$^{95}$ A preocupação do autor é oportuna, embora exija algumas ressalvas.

A primeira observação a ser feita diz respeito à aplicabilidade da norma extensivamente ao caso, pois não há vocação hereditária entre fiduciário e fideicomissário. Ora, sendo a dupla vocação hereditária um dos requisitos à caracterização do fideicomisso, a verificação de causa de indignidade deve estar restrita à relação entre fideicomitente e herdeiros. Não se trata de um ato de disposição de última vontade do fiduciário, mas do fideicomitente, razão pela qual a vontade desse último há que ser respeitada se contra ele não houver o fideicomissário incorrido em nenhuma das previsões do art. 1.814. Vale lembrar que está fora da alçada do fiduciário o cumprimento do fideicomisso, sendo indiferente a sua vontade. Por isso, parece exagero que o fideicomissário venha a perder o direito à herança deixada pelo fideicomitente apenas porque não permitiu que o fiduciário fizesse testamento, nos termos do art. 1.814, III, do Código Civil.

Por outro lado, é acertada a preocupação do autor em não se permitir que o fideicomissário possa se beneficiar de sua própria torpeza ao poder herdar após assassinar o fiduciário, que até então era o proprietário dos bens da herança. Seria certamente imoral que se permitisse ao fideicomissário antecipar o recebimento de sua herança tirando a vida do fiduciário. Por isso, embora não previsto na norma, deixar de aplicar à espécie por analogia o art. 1.814, I, do Código Civil, culminaria em uma premiação do criminoso. Portanto, pela mesma razão que é considerado indigno o herdeiro necessário que tenta contra a vida do autor da herança, ${ }^{96}$ também o fideicomissário que pratica o crime de

95 Art. 1.814. São excluídos da sucessão os herdeiros ou legatários: I - que houverem sido autores, coautores ou partícipes de homicídio doloso, ou tentativa deste, contra a pessoa de cuja sucessão se tratar, seu cônjuge, companheiro, ascendente ou descendente; II - que houverem acusado caluniosamente em juízo o autor da herança ou incorrerem em crime contra a sua honra, ou de seu cônjuge ou companheiro; III - que, por violência ou meios fraudulentos, inibirem ou obstarem o autor da herança de dispor livremente de seus bens por ato de última vontade.

96 Vale relembrar que o fideicomissário nunca terá a oportunidade de tentar tirar a vida do fideicomitente, uma vez que é requisito do fideicomisso que a morte desse último ocorra antes do nascimento daquele. 
homicídio contra o fiduciário deverá perder o direito à herança.

Entretanto, isso só tem sentido se a causa de resolução do fideicomisso prevista em testamento for a morte do fiduciário. Do contrário, nenhum proveito o fideicomissário estará tirando da situação, uma vez que os bens serão transmitidos à sucessão do fiduciário, consoante entendimento esposado por Pontes de Miranda anteriormente mencionado - ressalvada a hipótese em que o testamento estabelece termo ou condição no interesse do fiduciário, o qual desaparece com a sua morte. Assim, não sendo o fideicomissário premiado com a herança pela morte do fiduciário, não haveria razão para ceifar-lhe o direito de recebimento da herança que lhe foi deixada pelo fideicomitente.

A terceira ressalva ao entendimento de Venosa desvela-se no questionamento do porquê de limitar a aplicação da indignidade apenas em relação ao fideicomissário. Isso porque se o fideicomissário pode vir a se beneficiar com a morte do fiduciário, nos termos do parágrafo anterior, não menos verdadeira é a recíproca. Pelo contrário, o fiduciário sempre se beneficiará da morte do fideicomissário - diversamente do fideicomissário, que só terá vantagem se a causa de resolução do fideicomisso for a morte do fiduciário - com exceção da ressalva já feita por Pontes de Miranda. ${ }^{97}$ Destarte, também sobre o fiduciário deveria recair a sanção de perder o direito à herança caso seja autor ou partícipe de homicídio doloso, tentado ou consumado, contra o fideicomissário. Do contrário, estará o fiduciário sendo beneficiado pela própria torpeza ao provocar voluntariamente a caducidade do fideicomisso em seu favor.

\section{PARALELO COM O USUFRUTO}

Não são poucas as semelhanças existentes entre o fideicomisso e o usufruto, culminando inclusive em argumento $^{98}$ em favor da extinção do primeiro instituto quando da votação do Código Civil de 1916 no Senado, já mencionado.

Caio Mario da Silva Pereira ressalta que "a utilização de linguagem menos técnica, pelo testador, confunde, às vezes, as noções, denominando-os equivocadamente um pelo outro", o que vem causando aproximações perturbadoras no plano da aplicação prática ${ }^{99} \mathrm{Com}$ facilidade se 
pode ingressar em confusão entre as figuras: fideicomissário confunde-se com nu proprietário, fiduciário assemelha-se ao usufrutuário. A distinção é importante, pois "não importa muito o rótulo dado pelo testador, mas sua verdadeira intenção". ${ }^{100}$

Sobre o tema, Pontes de Miran$\mathrm{da}^{101}$ fez registro pontual sobre os fideicomissos construtivos, que em linhas gerais são aqueles em que surgia a necessidade de interpretação da vontade do testador, em observância ao art. 1.666 do Código revogado. ${ }^{102}$ Segundo esse raciocínio, o intérprete do testamento verificaria se, estando presente a figura de um pré-herdeiro ou de um pós-herdeiro, estaria o testador efetivamente buscando caracterizar aquilo que a lei prevê como o fideicomisso. Destarte, uma vez delimitado o papel de cada um dos sujeitos envolvidos nessa relação, poder-se-ia por meio de construção interpretativa da vontade do testador chegar à figura do fideicomisso quando lhe faltasse menção no testamento.

Orlando de Souza ${ }^{103}$ anota que as semelhanças entre o fideicomisso e o usufruto são patentes: fiduciário e usufrutuário têm a posse do bem, que no futuro será transferida a outrem. Além disso, há dever de prestação de caução tanto pelo fiduciário ${ }^{104}$ quanto pelo usufrutuário. ${ }^{105}$

No entanto, não obstante os efeitos práticos próximos, os institutos são em sua essência muito distintos, sendo o fideicomisso espécie de substituição testamentária e o usufruto instituição de direito real sobre coisa alheia. ${ }^{106}$ No usufruto o testador estabelece direitos diferentes, simultâneos e imediatos a duas pessoas, uma que terá a nua-propriedade e outra que terá o direito de uso e gozo. No fideicomisso há titulares sucessivos do mesmo direito - a propriedade. ${ }^{107}$

99 PEREIRA, op. cit., p. 281.

100 VENOSA, op. cit., p. 295.

101 PONTES DE MIRANDA, op. cit., p. 215-216.

102 CC/16, Art.. 1.666. Quando a cláusula testamentária for suscetível de interpretações diferentes, prevalecerá a que melhor assegure a observância da vontade do testador.

103 SOUZA, op. cit., p. 131-132.

$104 \mathrm{CC} / 02$, Art. 1.953, Parágrafo único. O fiduciário é obrigado a proceder ao inventário dos bens gravados, e a prestar caução de restitui-los se o exigir o fideicomissário. $105 \mathrm{CC} / 02$, Art. 1.400. O usufrutuário, antes de assumir o usufruto, inventariará, à sua custa, os bens que receber, determinando o estado em que se acham, e dará caução, fidejussória ou real, se lha exigir o dono, de velar-lhes pela conservação, e entregá-los findo o usufruto.

106 CARVALHO, op. cit., p. 58. 
Nesse instituto, o fideicomissário tem apenas uma expectativa de direito, não a propriedade; no usufruto, o nu proprietário efetivamente possui um direito, embora sem poder usar e gozar do bem. ${ }^{108}$

Enquanto há efetiva propriedade do fiduciário sobre os bens, que inclusive poderá vir a se tornar definitiva em caso de caducidade do fideicomisso, o mesmo não ocorre com o usufrutuário, uma vez que neste caso os bens gravados fatalmente passarão à posse dos proprietários em dado momento. A morte do fiduciário antes do termo ou condição implicará a transmissão dos bens à sua sucessão, enquanto a morte do usufrutuário extinguirá o usufruto. A morte do fideicomissário fará caducar o fideicomisso, conferindo a propriedade definitiva ao fiduciário; por outro lado, a morte do nu proprietário em nada altera os direitos do usufrutuário.

Ademais, como já esclarecido, no fideicomisso são contempladas pessoas ainda não concebidas, enquanto que no usufruto os destinatários já são nascidos, ${ }^{110}$ sendo esta uma das formas mais seguras de distinguir os institutos diante do molde atual da lei.
Até mesmo porque, ainda que a vontade do testador seja de uma substituição fideicomissária, por força do parágrafo único do art. 1.952 do Código Civil, caso o fideicomissário já tenha nascido haverá automática conversão para usufruto.

Orlando Gomes enriquece o rol de diferenças, elencando mais quatro:

No fideicomisso, a prescrição dos direitos e das ações da herança corre contra o fiduciário, bem como a usucapião do terceiro possuidor, ao passo que, no usufruto, corre contra o $n u$ proprietário.

O fiduciário pode reclamar as despesas com a valorização da coisa, enquanto o usufrutuário não tem esse direito.

Permitido é ao fiduciário alienar os bens fideicomitidos, constituir servidões e hipotecas, ainda que a alienação e os ônus constituídos se resolvam com a substituição, não podendo o usufrutuário praticar tais atos em razão da natureza de seu direito. $\mathrm{O}$ fiduciário não está obrigado a respeitar a destinação econômica do bem, como é de obrigação do usufrutuário. Finalmente, é lícito ao nu proprietário dispor do bem gravado, que transmite o ônus, ao passo que o fideicomissário não tem esse poder de dis-

107 WALD, op. cit., p. 165.

108 SOUZA, op. cit., p. 131.

109 GAMA, op. cit.

110 CARVALHO, op. cit., p. 58. 
posição enquanto estiver no domínio do fiduciário. ${ }^{111}$

Destarte, ao menos no campo teórico são inconfundíveis os institutos, o que vem em favor da reafirmação da utilidade do fideicomisso no ordenamento pátrio.

\section{FIDEICOMISSO NA DOAÇÃO}

De longa data é a discussão sobre a possibilidade de utilização do fideicomisso por ato inter vivos. Atualmente, há forte corrente doutrinária ${ }^{112}$ defendendo a possibilidade do fideicomisso em doação, em função do princípio da liberdade de estipulação negocial de que trata o art. 425 do Código Civil. ${ }^{113}$ Segundo Armando
Dias de Azevedo, o fideicomisso por ato inter vivos chegou até mesmo a ser utilizado em Portugal no período medieval. ${ }^{114}$

A corrente que defende essa possibilidade destaca que não há nenhuma vedação no Código Civil, de modo que o art. $4^{\circ}$ da Lei de Introdução ${ }^{115}$ autorizaria o uso da analogia e dos princípios gerais de direito para reconhecer a possibilidade de utilização do instituto entre vivos. ${ }^{116}$ Corroboram essa corrente Silvio Venosa ${ }^{117}$ e Arnoldo Wald. ${ }^{118}$

Pontes de Miranda ${ }^{119}$ esposou pensamento diverso, no sentido de que embora possuam algumas características assemelhadas, fideicomisso e doação com compromisso de transferência a outrem são coisas muito distintas, posição essa que veio a ser rebatida por Armando Dias de Azevedo. $^{120}$

111 GOMES, op. cit., p. 223.

112 CARVALHO, op. cit.

113 Art. 425. É lícito às partes estipular contratos atípicos, observadas as normas gerais fixadas neste Código.

114 AZEVEDO, Armando Dias de. O Fideicomisso no Direito Pátrio: Doutrina, Legislação, Jurisprudência. São Paulo: Saraiva, 1973, p. 11.

115 LINDB, Art. 4ํ Quando a lei for omissa, o juiz decidirá o caso de acordo com a analogia, os costumes e os princípios gerais de direito.

116 MALUF, Nagib Antônio. Fideicomisso no Direito Brasileiro. São Paulo: Hemus, 1987 , p. 19.

117 VENOSA, op. cit., p. 286.

118 WALD, op. cit., p. 166.

119 PONTES DE MIRANDA, op. cit., p. 198-199.

120 AZEVEDO, op. cit., p. 68-70. 
Caio Mario da Silva Pereira filia-se à corrente que resiste à aceitação do fideicomisso no campo das obrigações, destacando que "o fideicomisso é matéria peculiar ao direito das sucessões e, portanto, não deve exorbitar dele. E, como a tendência restritiva é crescente, sociologicamente deve prevalecer o entendimento contrário à sua expansão."121

Buscando auxílio no direito comparado, deparamo-nos com situação estranha no direito argentino, que veda a substituição fideicomissária ${ }^{122}$ mas autoriza expressamente, no art. 2.662 de seu Código Civil, ${ }^{123}$ o fideicomisso por ato inter vivos ${ }^{124} \mathrm{e}$, ainda, o fideicomisso singular por testamento, sendo esse último semelhante à figura do usufruto no direito brasileiro, cujo domínio é resolúvel e deve recair sobre bens determinados. ${ }^{125}$

No art. 962 do Código Civil de Portugal ${ }^{126}$ também há expressa pre- visão autorizando o fideicomisso nas doações. ${ }^{127}$

Em meio a essa discussão, Orlando Gomes apresenta brilhante conclusão sobre a questão, que parece ser, sobremaneira, a visão mais acertada:

A questão é malposta. A substituição fideicomissária constitui instituto típico do direito das sucessões, somente cabível quando resultante de determinação da vontade consubstanciada em testamento, que é o negócio jurídico mortis causa por excelência.

Cabimento não tem, evidentemente, trasladá-lo para o campo dos contratos.

Contudo, uma vez que, nesse terreno, reina o princípio da liberdade de contratar, nada impede que, no contrato de doação, as partes estipulem que o donatário fique obrigado a conservar os bens adquiridos para transmiti-los, por sua morte, a certo tempo, ou sob determinada condição, a pessoas nele designadas.

121 PEREIRA, op. cit., p. 275.

122 ZANNONI, op. cit., p. 603-604.

123 Art. 2.662. Dominio fiduciario es el que se adquiere en razón de un fideicomiso constituido por contrato o por testamento, y está sometido a durar solamente hasta la extinción del fideicomiso, para el efecto de entregar la cosa a quien corresponda según el contrato, el testamento o la ley.

124 CARREGAL, Mario Alberto. El fideicomisso: regulacion jurídica y possibilidades practicas. Buenos Aires: Universidad, 1982, p. 41.

125 ZANNONI, op. cit., p. 604.

126 "São admitidas substituições fideicomissárias nas doações."

127 ASCENSÃO, José de Oliveira. Direito Civil: sucessões. 5. ed. Coimbra: Coimbra Editora, 2000, p. 233. 
Esse negócio tem a mesma causa da substituição fideicomissária. Conduz, realmente, a igual resultado prático. Dado que a lei não o proíbe, nem é contrário aos bons costumes, pode ser constituído sob o único limite da regra geral contrária aos vínculos sucessivos. $^{128}$

De fato, aquilo que procura ser defendido como fideicomisso por ato inter vivos é, na verdade, apenas uma inspiração para atender às necessidades do doador. Ora, havendo autonomia das partes para a contratação, desde que não incorram em ilicitude, nenhum mal há em adotar o modelo do fideicomisso como um norte para tutelar a relação obrigacional a ser entabulada. De toda sorte, não se estará diante de genuíno fideicomisso pelas seguintes razões:

1. É requisito essencial do fideicomisso - sob pena de ser convertido em usufruto - que o fideicomissário ainda não tenha sido concebido. Obviamente essa exigência não se aplica ao campo das obrigações, podendo o doador estabelecer o destinatário final sem observância a tal limitação. Destarte, não estando restrito aos não concebidos, não há que se falar em fideicomisso - ao menos não nos termos da legislação brasileira.

2. Segundo ensinamento de Silvio Venosa, ${ }^{129}$ tudo que puder ser objeto de herança poderá ser objeto de fideicomisso. Todavia, em aparente contradição o autor também alerta que as doações não podem ser feitas a título universal, uma vez que exigem a identificação do objeto do negócio, sob pena de, por exemplo, impossibilitar a realização do registro de imóvel recebido. Destarte, inviabilizada a transferência patrimonial a título universal, não se está diante de genuíno fideicomisso, cujo objeto pode ser tanto legado quanto herança.

3. Não caberá a perda do direito por indignidade, apenas por ingratidão, ${ }^{130}$ nos termos do art. 555 do Código Civil. ${ }^{131}$ Em que pese tenham alguma

128 GOMES, op. cit., p. 211.

129 VENOSA, op. cit., p. 288.

130 FARIA, Mario Roberto Carvalho de. Direito das sucessões: teoria e prática. Rio de Janeiro: Forense, 2006, p. 201.

$131 \mathrm{CC} / 02$, Art. 555. A doação pode ser revogada por ingratidão do donatário, ou por inexecução do encargo. 
semelhança as hipóteses de ingratidão e de indignidade, os efeitos práticos são diferentes: o herdeiro indigno em regra não chega a adquirir a propriedade do bem, uma vez que é excluído da sucessão antes da partilha; de outra banda, o donatário ingrato terá o bem em seu domínio podendo vir a perdê-lo a qualquer tempo - desde que respeitado o prazo do art. 559 do Código. ${ }^{132}$

4. O parágrafo único do art. 547 do caderno civil ${ }^{133}$ apresenta-se como um grande óbice à defesa da teoria que se vale da cláusula de reversão como argumento para sustentar o fideicomisso nos atos inter vivos. ${ }^{134}$ Destarte, em observância ao referido dispositi- vo, restaria ser descartada a possibilidade de fideicomisso a ser resolvido pela morte do fiduciário, uma vez que em interpretação literal do referido dispositivo o patrimônio obrigatoriamente deveria retornar ao doador e não a um terceiro (fideicomissário).

Portanto, o que há nos atos inter vivos é um arremedo do fideicomisso, instituto este típico do direito das sucessões. Embora com efeitos práticos muito semelhantes, os requisitos e limites são diversos. Isso quer dizer que embora não se vede a feitura de contrato de doação que utilize a roupagem do fideicomisso, não se está efetivamente tratando do mesmo instituto, a despeito da eventual jurisprudência produzida em sentido contrário.

\section{REFERÊNCIAS}

ARGENTINA. Codigo Civil. Disponível em: <http://www.codigocivilonline. com.ar/>. Acesso em: 16 nov. 2013.
ASCENSÃO, José de Oliveira. Direito Civil: sucessões. 5. ed. Coimbra: Coimbra Editora, 2000.

132 Art. 559. A revogação por qualquer desses motivos deverá ser pleiteada dentro de um ano, a contar de quando chegue ao conhecimento do doador o fato que a autorizar, e de ter sido o donatário o seu autor.

133 Art. 547. O doador pode estipular que os bens doados voltem ao seu patrimônio, se sobreviver ao donatário. Parágrafo único. Não prevalece cláusula de reversão em favor de terceiro.

134 AZEVEDO, op. cit., p. 59. 
AZEVEDO, Armando Dias de. Do fideicomisso. Porto Alegre: Boa Imprensa, 1938.

AZEVEDO, Armando Dias de. $O$ Fideicomisso no Direito Pátrio: Doutrina, Legislação, Jurisprudência. São Paulo: Saraiva, 1973. BARROSO, Luís Roberto. Interpretação e aplicação da constituição: fundamentos de uma dogmática constitucional transformadora. 4. ed. rev. e atual. São Paulo: Saraiva, 2001.

BEVILAQUA, Clóvis. Direito das sucessões. 3. ed. Rio de Janeiro: Livraria Editora Freitas Bastos, 1938.

BIANCA, C. Massimo. Diritto Civile. La famiglia. Le successioni, v. 2. 3. ed. Milano: Giuffrè, 2001.

BORGHI, Hélio. O novo Código Civil e as inovações no direito das sucessões: a nova forma de substituição fideicomissária. In: Revista de Direito Privado, v. 8, n. 31, p. 91-118.

BRASIL. Código Civil. Diário Oficial da União, Poder Executivo, Brasília, DF, 11 jan. 2002. Disponível em: <http://www.planalto.gov.br/ ccivil_03/leis/2002/110406.htm>. Acesso em: 16 nov. 2013.

BRASIL. Lei de Introdução às normas do Direito Brasileiro. Diário Oficial da União, Poder Executivo, Brasília, DF, 04 set. 1942. Disponível em: <http://www.planalto.gov.br/ccivil_03/leis/2002/ 110406.htm>. Acesso em: 16 nov. 2013.

CARVALHO, Luiz Paulo Vieira de. Direito das sucessões: das substituições no Código Civil de 2002. In: Revista de Direito do Tribunal de Justiça do Rio de Janeiro. Rio de Janeiro, n. 66, p. 42-59, jan. 2006.

CARREGAL, Mario Alberto. El fideicomisso: regulacion jurídica y possibilidades practicas. Buenos Aires: Universidad, 1982.

FARIA, Mario Roberto Carvalho de. Direito das sucessões: teoria e prática. Rio de Janeiro: Forense, 2006.

GAMA, Guilherme Calmon Nogueira da. Substituições e fideicomisso. In: HIRONAKA, Giselda Maria Fernandes Novaes; PEREIRA, Rodrigo da Cunha. Direito das sucessões e o novo código civil. Belo Horizonte: Del Rey, 2004.

GAIUS. Institutas do jurisconsulto Gaio. Tradução: CRETELLA Jr., J.; CRETELLA, Agnes. São Pau1o: Editora Revista dos Tribunais, 2004.

GOMES, Orlando. Sucessões. 12. ed. Rio de Janeiro: Editora Forense, 2004.

ITÁLIA. Il Codice Civile Italiano. Disponível em: <http://www. ilcodicecivile.it/>. Acesso em: 15 jul. 2014.

LEITE, George Salomão. Interpretação Constitucional e Tópica Jurí- 
dica. São Paulo: Juarez de Oliveira, 2002.

MALUF, Nagib Antônio. Fideicomisso no Direito Brasileiro. São Paulo: Hemus, 1987.

MEIRA, José Corrêa de. Do fideicomisso: apontamentos de um juiz sobre as substituições fideicommisarias em geral. Analyse das principaes questões. São Paulo: Livraria Acadêmica Saraiva \& Cia., 1929.

MOREIRA ALVES, José Carlos. Direito Romano. 14. ed. Rio de Janeiro: Editora Forense, 2008.

PEREIRA, Caio Mário da Silva. Instituições de Direito Civil: direito das sucessões. v. 4. 17. ed. Rio de Janeiro: Editora Forense, 2009.

PONTES DE MIRANDA, Francisco Cavalcanti. Tratado de direito privado. T. LVIII. Atualizado por Giselda Hironaka e Paulo Lôbo. São Paulo: Editora Revista dos Tribunais, 2012.

PORTUGAL. Código Civil. Ministério da Justiça, 25 nov. 1966. Dis- ponível em: <http://www.pgdlisboa.pt/leis/lei_mostra_estrutura. php?tabela=leis\&artigo_id=\&ni $\mathrm{d}=775 \&$ nversao $=\&$ tabela $=$ leis $>$. Acesso em: 16 nov. 2013.

RIZZARDO, Arnaldo. Direito das sucessões: Lei n. 10.406, de 10.01.2002. 2. ed. Rio de Janeiro: Forense, 2005.

RODRIGUES, Silvio. Direito civil: direito das sucessões, v. 7. 26. ed. São Paulo: Saraiva, 2003.

SOUZA, Orlando de. Prática dos testamentos. 1. ed. São Paulo: Sugestões Literárias S/A, 1969.

VENOSA, Silvio de Salvo. Direito civil: direito das sucessões. 6. ed. São Paulo: Atlas, 2006.

WALD, Arnoldo. Curso de direito civil brasileiro: direito das sucessões. v. 5. 8. ed. São Paulo: Editora Revista dos Tribunais, 1991.

ZANNONI, Eduardo A. Manual de derecho de las sucesiones. 4. ed. Buenos Aires: Editorial Astrea, 1999. 